Goran Radoš

University of Zagreb

Faculty of Croatian Studies

10000 Zagreb, Croatia

grados@hrstud.hr
Irena Pandža Bajs

University of Zagreb

Faculty of Economics \& Business

10000 Zagreb, Croatia

ipandza@efzg.hr
JEL: $M, L 31$

Original scientific article

https://doi.org/10.51680/ev.34.1.4

Received: March 4, 2020

Revision received: June 15, 2020

Accepted for publishing: June 16, 2020

Danijela Martinović

University of Sarajevo

School of Economics and Business

71000 Sarajevo,

Bosnia \& Herzegovina

Creative Commons Attribution-

NonCommercial-NoDerivatives 4.0 International License

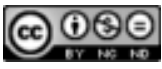

danijela.martinovic@efsa.unsa.ba

\title{
SOCIAL
}

\section{ENTREPRENEURIAL INTENTIONS AND MOTIVATIONAL DRIVERS AMONG BUSINESS STUDENTS}

\begin{abstract}
Purpose: The paper is aimed at determining young people's motives and views related to entrepreneurship, in particular social entrepreneurship. To this purpose, a survey was conducted at the School of Economics and Business in Sarajevo to explore the motivations of the student population to pursue entrepreneurship, with a focus on social entrepreneurship and their intentions to engage in it. The survey examined sociopolitical, situational and personal factors and their direct and mediating effect on the intention to engage in social entrepreneurship.
\end{abstract}

Methodology: The research model and methodology presented in the paper are based on the process theory of motivation and the model used by Barton et al. (2018) and by Krueger (1993). The model elaborated by this paper's authors is expanded and redefined so as to take account of socio-political factors and the respondents' views of them.

Results: The research revealed a limiting and de-stimulating effect of environmental factors on the intention to start a business, as well as the significance of situational and personal factors when deciding on engaging in social entrepreneurship.

Conclusion: The conducted research revealed that young people in Bosnia and Herzegovina understand the significance of social entrepreneurship for society at large, as well as for themselves, i.e. the sense of fulfilment it could bring. The results could suggest that, for the respondents, the desirable entrepreneurial option would be the one that implies involvement not in the social entrepreneurship but in the socially responsible entrepreneurship.

Keywords: Social entrepreneurship, motivational drivers, socio-political, situational and personal factors

\section{Introduction}

Social entrepreneurship is a form of entrepreneurship that, besides profit-based goals, endeavours to achieve altruistic, socially responsible and desirable goals. Social enterprises encompass a broad spectrum of entities that create social value and promote social good, and that endeavour to contribute 
to general social wellbeing and progress. The aims related to broader implementation of social entrepreneurship are an inseparable part of a series of European strategies and action plans.

Due to the significance of this topic and the fact that it is insufficiently represented in business theory and practice in Bosnia and Herzegovina $(\mathrm{BiH})$, our research focuses on social entrepreneurial intentions and motivational drivers among business students. The paper is aimed at determining young people's motives and views related to entrepreneurship in general, and in particular to social entrepreneurship. The research model included socio-political, situational and personal factors as variables affecting the intention to engage in social entrepreneurship. The aim was to determine young people's views and affinities for entrepreneurship in general and in particular social entrepreneurship, i.e. identify factors that have a stimulating or de-stimulating effect on their entrepreneurial intentions.

The paper is structured as follows: An overview of literature that elaborates the concept and nature of social entrepreneurship and motives that affect the students' entrepreneurial intentions is followed by the section that explores the experience and practices of social entrepreneurship in Europe and $\mathrm{BiH}$. The research section of the paper describes the structure of the sample and research methodology, and presents research results followed by discussion and elaboration. Limitations of the research and recommendations for future research are also included. The paper ends with a conclusion and a list of references.

\section{Social entrepreneurship - theoretical review}

The concept of social entrepreneurship (SE) first appeared in the economic literature in the 1980s. Over time, the understanding of this category of enterprises has changed and expanded - from not-for-profit organisations, NGOs and foundations (Henton et al., 1997; Moore \& Prabhu, 2018), i.e. non-profit organisations with earned income strategies, to for-profit organisations driven by socially useful goals (AbuSaifan, 2012, p. 26; Noruzi et al., 2010).

Social enterprises encompass a broad range of enterprises that create social capital and promote the public good (Leadbeater, 1997; Moore, 2018), recognise key social issues (Thompson et al., 2000;
Ashoka, 2012 $)$, and endeavour to contribute to social (Zahra et al., 2008, as cited in Abu Saifan, 2012) and economic wellbeing (Nga \& Shamuganathan, 2010), i.e. enterprises that are "dedicated to solving social, economic and environmental problems" (Yunus, 2011; Mair \& Marti, 2006). Robinson, Mair and Hockerts (2009) believe that social entrepreneurship was initiated by mistakes in the social sector related to "inefficient distribution and provision of public/social goods", and that the task of social entrepreneurship includes bringing about systemic social change (Leadbeater, 1997; Dees, 1998) and the redistribution of wealth (Austin, 2004).

Thus, "a social entrepreneur is a path breaker with a powerful new idea who combines visionary and real-world problem-solving creativity, has a strong ethical fibre, and is totally possessed by his or her vision for change" (Bornstein, 1998). For Leadbeater (1997) social entrepreneurs are "entrepreneurial, innovative and transformatory" individuals who are also: "leaders, storytellers, people managers, visionary opportunists and alliance builders". They recognise social problems and organise, create and manage a venture to bring about social change. Abu-Saifan (2012) defines a social entrepreneur as "a mission-driven individual who uses a set of entrepreneurial behaviours to deliver a social value to the less privileged, all through an entrepreneurially oriented entity that is financially independent, selfsufficient, or sustainable". Dees (1998) believes that social entrepreneurs have the role of "change/transformation agents in the social sectors" and that "the social entrepreneur aims for value in the form of large-scale, transformational benefit that accrues either to a significant segment of society or to society at large" (Roger \& Osberg, 2007).

\section{Motives for involvement in entrepreneurship and social entrepreneurship}

The economic literature lists different reasons for engaging in entrepreneurship and social entrepreneurship. A distinction is made between motivational drivers and entrepreneurial intentions. Motivation affects intention, while intention results in actual action. Motivational drivers and entrepre-

\footnotetext{
1 Ashoka, Largest Support Network for Social Entrepreneurs (2012), available at: https://www.ashoka.org/en/focus/socialentrepreneurship
} 
neurial intentions make up a single set of elements which does or does not lead to an actual result - a person's entrepreneurial activity.

Social entrepreneurs are motivated by their desire to have a social impact and to solve social problems (Barton et al., 2018), and their motives are more numerous and complex than those driving traditional, profit-oriented entrepreneurs. Germak and Robinson (2013) highlight the following motivating factors that drive engagement in social entrepreneurship: personal fulfilment; helping society; nonmonetary focus; achievement orientation; and closeness to social issues. Moreover, the need for personal fulfilment (self-actualisation) includes not only the desire to start a business and be one's own boss but also social achievement and the desire for self-actualisation by helping one's own community (Germak \& Robinson, 2013). Leadbeater (1997), Prabhu (1999), and Shaw and Carter (2007) obtained similar results in their research. A strong desire to help society is also one of crucial motivational drivers (Perry 1997; Germak \& Robinson, 2013), and the same is true of nonmonetary focus and closeness to social problems (Perry \& Wise, 1990; Wong \& Tang, 2007). Research by Shaw and Carter (2007) reached the conclusion that altruistic goals are dominant motives for engaging in social entrepreneurship. Goals that prevail in a traditional entrepreneur (change of career, greater independence, desire for independence, securing livelihood, etc.) were rated as less relevant.

Factors that act as motivational drivers and affect social entrepreneurial intentions and the intention to pursue business in general are numerous and can be classified into two groups: situational and individual (Shapero \& Sokol, 1982; Braga et al., 2015). In psychology, situational factors are outside, environmental elements and are not related to a person's nature and characteristics.

"Situational factors (also known as external factors) are influences that do not occur from within the individual but from elsewhere like the environment and others around you. Examples of situational factors are your environment, work and school, and the people around you"2.

2 Available at: https://www.alleydog.com/glossary/definition.ph p?term $=$ Situational+Factors $+\% 28$ also + Known + As + External $+F$ actors\%29
Contrary to situational factors, individual factors are related to the individual, their personality, and include their perception, views and behaviour (i.e. result in differences in perception, views and behaviour).

\section{Social entrepreneurship-experiences and practices in the $\mathrm{EU}$ and $\mathrm{BiH}$}

In the EU, social entrepreneurship accounts for $10 \%$ of the total entrepreneurial activity across the EU and employs 6\% of all workers. This type of entrepreneurship is a crucial form of entrepreneurial activity that employs vulnerable population categories, thus contributing to social inclusion and integration $^{3}$.

Guided by the objectives of the Europe 2020 strategy, which promotes integrated, smart, sustainable and inclusive growth, the EU Member States make considerable efforts to foster the development of entrepreneurship in general (Small Business Act and Charter for Small Enterprises) and the development of social entrepreneurship. Cooperatives of Social Solidarity have been established in Germany, Italy, Spain and Portugal; the United Kingdom and France have introduced community interest companies, which promote general social goals and serve a broader social community. A great assistance to the establishment of social entrepreneurship and the networking of social entrepreneurs of South East European countries in the exchange of experiences and sharing of best practices is provided by the Eco Social Economy Network South and East Europe (ESENSEE) and by the European Union through the Europe for Citizens Programme, whose active participants include Croatia, Serbia, Macedonia, Montenegro, Slovenia and, as of recently, Bosnia and Herzegovina (See more in: International Swedish Institute for Public Administration, 2012).

In $\mathrm{BiH}$, a third of the population live in poverty or on the edge of poverty, and as much as $60 \%$ are socially excluded. This fact confirms the need for developing entrepreneurship in general to promote self-employment and income generation, as well as social entrepreneurship, to achieve its social objectives and focus on the vulnerable population

\footnotetext{
3 Available at: www.emes.net, Social entrepreneurship in the EU - Recent trends
} 
categories. It should be noted here that economic scholars believe that traditional entrepreneurship has a social component as well, since it reduces unemployment and poverty by providing employment to the population, and contributes to the successful functioning of the state through payment of taxes. Between traditional entrepreneurship and social entrepreneurship, there is socially responsible entrepreneurship which, although it has profit as its primary goal, contributes to the human, social and ecological goals of the society through its activities. Companies that invest considerable funds in supporting community development in Bosnia and Herzegovina, include BH Telecom, Tondach, Cementara Kakanj etc.

The legal framework for traditional entrepreneurship (small and medium-size enterprises) is not developed in Bosnia and Herzegovina (there is no umbrella state law which regulates this subject matter; there is no state agency for small and medium-size enterprises or a fund for their support). The laws and regulations that govern business/entrepreneurial activities are overlapping and inconsistent, and have been delegated to lower levels of government, i.e. entities and cantons. Appropriate systematic measures for financial and technical support are lacking (Martinović, 2014).

The situation is even worse in terms of laws and regulations concerning social entrepreneurship and institutional programmes of support for social entrepreneurship at the level of $\mathrm{BiH}$. The Strategy for social inclusion (as part of the Strategy for the development of $\mathrm{BiH}$ ), which provided a framework for supporting social entrepreneurship in $\mathrm{BiH}$, has not been adopted yet. The failure to adopt these crucial documents primarily arose from political disagreements and insufficient awareness of the concept and significance of social entrepreneurship. Entities have adopted laws that stipulate that companies that employ the disabled, the displaced, refugees and returnees are entitled to financial support. In other words, the law prescribes the percentage of disabled people that a company has to employ to receive the support. The Act on Games of Chance of the Federation $\mathrm{BiH}$ specifies the percentage of the prize money earned from the games which is to be paid to relief organisations of all three constituent nations, while $50 \%$ of the income of the Federation
$\mathrm{BiH}$ is distributed, on the same basis, to organisations involved in the protection of children and minors, disabled persons, Solidarity Fund for Medical Treatment, sports associations, cultural institutions, food banks, etc. (See more in: International Swedish Institute for Public Administration, 2012).

Support programmes at a local level (that of cantons and municipalities) are implemented sporadically and to a great extend depend on the local community's understanding for social entrepreneurs' projects.

In $\mathrm{BiH}$, social entrepreneurship is mostly associated with activities by non-governmental organisations (NGOs). There are as many as 12,000 in $\mathrm{BiH}, 60 \%$ of which are active at a local level and provide services for $29 \%$ of citizens (See more in: International Swedish Institute for Public Administration, 2012; Spahić \& Šarić, 2017).

Other forms of social entrepreneurship (organisations) are not sufficiently established in $\mathrm{BiH}$. Although there are a great number of non-governmental organisations, i.e. social entrepreneurs, the biggest barriers to SE development, as pointed out by SE managers include the lack of awareness of their mission and significance, arbitrary criteria for awarding resources, and the lack of comprehensive regulations on SE activity.

\section{Research methodology}

With the aim of determining students' entrepreneurial motives and intentions, a survey was conducted of 100 first-year students at the School of Economics and Business of the University of Sarajevo (SEBS), in October 2019. The objective was to examine the views of young people who, based on their selection of study programme, were expected to have more knowledge of and affinity for entrepreneurship and social entrepreneurship. The focus was on first-year students, i.e. persons aged 19, on average, who had no previous experience with entrepreneurship and were not (self-)employed. The students participated in a written survey - out of 100 survey questionnaires, a total of 87 were filled in and returned.

Demographic data on the respondents are shown in Figure 1. 



Source: Authors' research

Structure of the questionnaire: The questionnaire consisted of three parts. The first part included demographic questions, the second examined the respondents' views on entrepreneurship in general, and the third inquired about their attitudes towards social entrepreneurship. The questions in the second part were designed based on the questionnaire by Rantanan et al. (2015) and the questionnaire used in the GEM research ${ }^{4}$, which inquired about the respondents' entrepreneurial motivation and intentions, and entrepreneurial environment. The third part was designed based on the questionnaire used by Barton et al. (2018). In the third part of the questionnaire, the authors included the effect of sociopolitical environment as an additional factor not used by Barton et al. (2018) in their work. The ques-

4 Globalni monitor poduzetništva - GEM, available at: http:// www.cerpod-tuzla.org/index.php/bs/gem/o-gem-projektu tionnaire consisted of 45 questions and statements in total. It used a seven-point Likert scale, with ratings from 1 (strongly disagree) to 7 (strongly agree).

Research model and methodology: Research model and methodology presented in the paper are based on the model used by Barton et al. (2018) and by Krueger (1993), which combines models developed by Ajzen (1991) and that of Shapero and Sokol (1982). Barton et al's model is based on the process theory of motivation, which "describes the existing behaviour and 'how' behaviour occurs, i.e., how an individual is motivated" (Barton et al., 2018, p. 14). The authors believe that the intention to engage in social entrepreneurship is affected by perceived feasibility and perceived desirability as mediators. "The term perceived feasibility relates to the extent to which an individual believes they have the capability to start a new venture. The term perceived 
desirability relates to how appealing it is to an individual to generate an entrepreneurial event such as starting a venture" (Barton et al., 2018, p. 17). Perceived feasibility and perceived desirability, respectively, are affected by a number of variables. Authors Barton et al. (2018) essentially classify variables into two groups: "semi-situational" factors, which affect perceived feasibility, and individual factors, which affect perceived desirability. The "semi-situational" factors are not presented as an objective, external category but rather as subjective factors shaped by the environment (an individual's previous experience with entrepreneurship or volunteering affects the perceived feasibility, entrepreneurial education, self-efficacy as well as internal locus of control - a belief that one's actions, rather than chance, lead to entrepreneurial success). Individual factors, as we pointed out, pertain to an individual's personality i.e. individual characteristics, which are evident in the person's values, needs, and attitudes.

When discussing research limitations, Barton et al. (2018) suggest that future research should include socio-political factors, which show how the sociopolitical environment and entrepreneurial climate affect motivation and intention to engage in entrepreneurship and social entrepreneurship.

The model elaborated by this paper's authors is based on the model developed by Barton et al. (2018). It was expanded and redefined so as to take account of socio-political factors and respondents' views of them. The paper presents two groups of socio-political factors: those that affect entrepreneurial intention in general, and factors that have a stimulating or de-stimulating effect on engaging in social entrepreneurship.

Thus, the survey examined the effect of socio-political factors, semi-situational factors and personal factors, and their direct and mediating effect on the intention to engage in social entrepreneurship.

Socio-political factors include political, regulatory, and social environment, i.e. government policies and programmes, commercial and legal infrastructure, education system, financial system, development of internal market, and other factors. They constitute a stimulating or de-stimulating framework for entrepreneurial intention.

Semi-situational factors are factors that affect the intention to engage in entrepreneurship. They include entrepreneurial education and respondents' understanding and belief that they are capable of engaging in social entrepreneurship. Personal factors include respondents' personal characteristics: their need to achieve business and financial success, recognition, independence, or self-fulfilment and personal development.

The paper examines motivational factors among students related to social entrepreneurship in Bosnia and Herzegovina. Papers and studies examining this topic among students in $\mathrm{BiH}$ are few and far between. Thus, this paper makes a contribution to the advancement of knowledge in this research field in $\mathrm{BiH}$.

\section{Results and discussion}

Basing our research on the process-based motivation theories and Krueger's model, we assumed that perceived desirability and perceived feasibility are two most significant predictors of social entrepreneurship intention. They have a mediating effect on social entrepreneurship intention, as a dependent variable. Survey questions: How much would you like social entrepreneurship? How enthusiastic would you be? How stressed out would you be? are used to determine the respondents' perceived desirability, while questions: How hard do you think it would be? and How busy do you believe you would be? seek to determine the degree of perceived feasibility.

These questions are used to prove or disprove the first hypothesis (H1), which claims:

There is a positive relationship between perceived desirability and social entrepreneurship intention, and to prove or disprove the second hypothesis (H2), which claims: There is a positive relationship between perceived feasibility and social entrepreneurship intention.

By means of path analysis, it was established that both perceived desirability and perceived feasibility have a direct positive relationship with social entrepreneurship intention.

Naturally, the discussion of these variables needs to take into account different motives that affect social entrepreneurship intention, i.e. perceived desirability and perceived feasibility individually. The antecedents of perceived feasibility are entrepreneurial education, experience, entrepreneurial self-efficacy, and internal locus of control. It is assumed that respondents' (favourable) previous entrepreneurial experience, entrepreneurial education, entrepreneurial self-efficacy and the belief that 
it is by their own action (rather than by chance) that they will achieve entrepreneurial results will have a positive effect on perceived feasibility and thus, indirectly, as a mediator, on the social entrepreneurship intention. These claims were examined through hypotheses H3-H6.

Inclusion of these variables (predictors) in the model confirmed a statistically significant positive relationship between social entrepreneurship intention and perceived feasibility.
The antecedents of perceived desirability are impact, wealth, self-realisation, authority, autonomy, and challenge. In other words, perceived desirability is affected by the respondents' need to achieve a result, to achieve financial success, personal development, gain recognition, independence, and to implement one's ideas. These claims were tested through hypotheses H8-H12.

The survey data, analysed using the STATA software, are shown in Table 1 and Table 2:

\section{Table 1 Path analysis}

\begin{tabular}{|c|c|c|c|c|c|c|}
\hline Standardised & Coef. & Std. Err & $\mathbf{z}$ & $\mathbf{P}>|\mathbf{z}|$ & \multicolumn{2}{|c|}{ 95\% Conf. Interval } \\
\hline \multicolumn{7}{|l|}{ pf_av } \\
\hline eex01 & .0896325 & .0916062 & 0.98 & 0.328 & -.0899125 & .2691774 \\
\hline edu_av2 & .0618776 & .1100373 & 0.56 & 0.574 & -.1537945 & .2775467 \\
\hline ese_av & .42465 & .0960003 & 4.42 & $\underline{0.000}$ & .2364929 & .6128071 \\
\hline lc_av1 & .2868188 & .0978813 & 2.93 & $\underline{0.003}$ & .094975 & .4786626 \\
\hline _cons & 0 (constrained) & & & & & \\
\hline \multicolumn{7}{|l|}{ pd_av } \\
\hline wo & .3257762 & .130265 & 2.50 & $\underline{\underline{0.012}}$ & .0704615 & .5810909 \\
\hline sro & .09516 & .1464665 & 0.65 & 0.516 & -.1919092 & .3822291 \\
\hline auth & .1726773 & .1455692 & 1.19 & 0.236 & -.1126331 & .4579877 \\
\hline auto & -.1564356 & .1270593 & -1.23 & 0.218 & -.4054672 & .0925961 \\
\hline co & .2128459 & .1457977 & 1.46 & 0.144 & -.0729123 & .4986041 \\
\hline _cons & 0 (constrained) & & & & & \\
\hline \multicolumn{7}{|l|}{ sei } \\
\hline pf_av & .2525621 & .0867522 & 2.91 & $\underline{\underline{0.004}}$ & .082531 & .4225932 \\
\hline pd_av & .7469098 & .0606371 & 12.32 & $\underline{\underline{0.000}}$ & .6280633 & .8657564 \\
\hline male & -.002922 & .0634145 & -0.05 & 0.963 & -.127212 & .1213681 \\
\hline age & -.0828042 & .008823 & -9.39 & $\underline{\underline{0.000}}$ & -.100097 & -.0655114 \\
\hline _cons & 0 (constrained) & & & & & \\
\hline var(e.pf_av & .5707152 & .0445365 & & & .489773 & .6650343 \\
\hline var(e.pd_av) & .6278463 & .0485284 & & & .5395864 & .7305428 \\
\hline var(e.sei & .2615696 & .0500801 & & & .1797282 & .3806785 \\
\hline
\end{tabular}

Source: Authors' calculations 
Table 2 Examination of hypotheses

\begin{tabular}{|l|c|}
\hline Results of Path Analysis & $\begin{array}{c}\text { Parameter Estimate (stan- } \\
\text { dardised) }\end{array}$ \\
\hline Perceived Desirability -> SEI (H1) & $0.746^{* * * *}$ \\
Perceived Feasibility -> SEI (H2) & $0.252^{* * * *}$ \\
Entrepreneurship Experience -> SEI (H3) & 0.089 \\
Entrepreneurship Education -> Perceived Feasibility (H4) & 0.061 \\
Entrepreneurial Self-Efficacy -> Perceived Feasibility (H5) & $0.424^{* * * *}$ \\
Locus of Control -> Perceived Feasibility (H6) & $0.286^{* * *}$ \\
Wealth Objective -> Perceived Desirability (H8) & $0.325^{*}$ \\
Self-Realisation Objective -> Perceived Desirability (H9) & 0.095 \\
Authority Objective $->$ Perceived Desirability (H10) & 0.172 \\
Autonomy Objective -> Perceived Desirability (H1) & -0.156 \\
Challenge Objective $->$ Perceived Desirability (H12) & 0.212 \\
\hline
\end{tabular}

**** p-value $<0.001 ;$ ** p-value $<0.01 ; *$ p-value $<0.05 ;+$ p-value $<0.10$

Source: Authors' calculations

Meaning of variables in the model:

- Perceived desirability (pd_av)

- Perceived feasibility (pf_av)

- Entrepreneurship experience (eex01)

- Entrepreneurship education (edu_av2)

- Entrepreneurial self-efficacy (ese_av)

- Locus of control (lc_av1)

- Wealth objective (wo)

- Self-realisation objective (sro)

- Authority objective (auth)

- Autonomy objective (auto)

- Challenge objective (co)

- Social entrepreneurship intention (sei)

Inclusion of these predictors in the model confirmed a statistically significant positive relationship between social entrepreneurship intention and perceived desirability. Furthermore, there is a statistically significant positive relationship between social entrepreneurship intention and perceived feasibility. Thus, hypotheses $\mathbf{H 1}$ and $\mathbf{H} \mathbf{2}$ have been confirmed.

Research results revealed that the following two variables have a statistically significant (positive) effect on perceived feasibility: Entrepreneurial selfefficacy (respondents' entrepreneurial self-efficacy)
(H5) and locus of control (respondents' belief that they will achieve the desired goals through their own effort and actions) (H6).

One variable has a statistically significant (positive) effect on perceived desirability: Wealth objective (wellbeing related to the possibility of earning a higher income) (H8).

Other hypotheses have not been confirmed.

With the aim of giving an additional contribution, socio-political factors were included in the research, i.e. the survey also examined the respondents' attitudes towards the political, regulatory, and social environment, i.e. government policies and programmes, commercial and legal infrastructure, education system, financial system, development of internal market, and other factors. These factors constitute a stimulating or de-stimulating framework for entrepreneurial intention. However, no direct significant relationship with social entrepreneurship intention was established. The inclusion of these variables did not change the initial model or the established significance.

In addition, instruments of descriptive statistics were used to explain the obtained results. The results of descriptive statistics (SEM) are presented in the appendix.

An analysis of survey questionnaires established that the respondents had no previous entrepre- 
neurial experience or entrepreneurial education. Only $17 \%$ of them are or used to be employed, while $13 \%$ attempted to start or started their own business. The respondents believe that they have the basic knowledge of entrepreneurship (average rating 4.82 , i.e. $59 \%$ of them agree with the statement, with ratings from 5 to 7 on a seven-point Likert scale, but have no practical entrepreneurial experience (rating 3.02) or knowledge of managerial skills and abilities (ratings 4.23 and 4.46, respectively). These results can be explained by the structure of convenience sample - the focus was on young people, first-year university students (average age: 19) who enrolled in the university immediately after completing secondary education and did not have time (or desire), or opportunity to engage in entrepreneurship. In addition, most surveyed respondents (47\%) completed secondary school of business and had some basic (theoretical) knowledge of entrepreneurship. The basic knowledge and the young people's mind-set resulted in a high level of respondents' self-confidence in their entrepreneurial ability - the respondents believe that they can successfully start and develop a small business (rating 5.3), and that their knowledge and action will lead to entrepreneurial success (rating 5.5). The lack of experience and entrepreneurial education and a high level of self-efficacy and internal locus of control resulted in a positive relationship between perceived feasibility and (social) entrepreneurship intention. The lack of experience affected the respondents' responses related to business conditions as well as technical and entrepreneurial infrastructure available to entrepreneurs. They indicated not knowing whether conditions for doing business in $\mathrm{BiH}$ are favourable or not (ratings $3.6-4.19$ ). Their responses pertaining to motives for engaging in entrepreneurship suggest that they are opportunitydriven, rather than necessity-driven, which is consistent with the findings of the GEM study, which reveals (contrary to expectations) a high share of opportunity entrepreneurs in $\mathrm{BiH}$. Indeed, in less developed and transition countries, the entrepreneurial activity index (TEA index) is high, as well as the share of necessity entrepreneurs. Developed countries, regardless of the value of entrepreneurial activity index, have a higher share of opportunity entrepreneurs. The respondents expressed a strong entrepreneurial intention and social entrepreneurship intention (over $55 \%$ of them claim that they want to engage in social entrepreneurship, $50 \%$ that they want to engage in entrepreneurship, $30 \%$ are not sure, $20 \%$ claim that they do not want to engage in entrepreneurship, while $15 \%$ do not want to engage in social entrepreneurship). Students believe that they are capable of engaging in entrepreneurship (rating 5.23) and that the main motivator is the observed opportunity that should be exploited (rating 4.98).

Based on the above, it can be concluded that the respondents (SEBS students) have no entrepreneurial experience and knowledge but that they are willing to engage in entrepreneurship in general, and in social entrepreneurship. Moreover, they are confident about their entrepreneurial success.

The primary motives for engaging in social entrepreneurship, as indicated by students, are altruistic goals - a desire to improve society at large (rating 5.86) and a desire to improve employees' position (rating 5.94). They also expressed concern that engagement in social entrepreneurship will be demanding and stressful (5.13 and 5.93, respectively). It seems that students who claimed that they do not want to engage in social entrepreneurship are not aware of the significance of social entrepreneurship (5.7), or believe that engagement in social entrepreneurship is demanding (4.97), stressful (4.82), and that the state does not provide support to social entrepreneurship (4.9), does not promote social entrepreneurship (4.6), and does not recognise its significance. The respondents believe that, instead of engaging in entrepreneurship and social entrepreneurship, and instead of work in a privately-owned enterprise as an employee, their desirable career would include employment in civil service (4.94).

As already pointed out, the high (unrealistic) selfconfidence can be ascribed to students' youthful enthusiasm, some theoretical knowledge of the essence and nature of entrepreneurship, mind-set (culture), and impact of environment - primarily parents. These factors should be viewed in synergy.

Students' youthful enthusiasm: Research on students' entrepreneurial optimism and overconfidence across cultures revealed that there is a high degree of optimism and self-confidence related to entrepreneurial intention across the world (Giacomin et al., 2016). A number of authors (Trevelyan, 2008; Forbes, 2005) established a remarkable significance of optimism and overconfidence among economic students related to the intention to start a business. Optimism and overconfidence of the entire student population were confirmed in a num- 
ber of studies (Bell \& Vockmann, 2011; Saunders et al., 2009; Nowell \& Alston, 2007). In analysing economic students' ability to predict their exam performance, Grimes (2002) established that students' overconfidence is affected neither by race nor by gender; it is negatively affected by the respondents' age. More specifically, older students, who had more experience with exams, were less likely to over-estimate their own economic knowledge and exam performance. Interestingly, these results coincide with the results obtained by the authors of this paper. In our research, students showed a lot of optimism and a bit of overconfidence, since they were convinced that they have the knowledge and ability to engage in entrepreneurship and social entrepreneurship. Similar to Grimes' research, there were no differences among different genders, while the respondents' age had a statistically significant negative effect in this research as well (see Table 1). Older respondents expressed less enthusiasm and willingness to get involved in either entrepreneurship or social entrepreneurship, i.e. a lower level of entrepreneurial intention. A statistically significant effect of the place of residence, income or level of education of the respondents' parents was not found.

The belief that they have some theoretical knowledge of the essence and nature of entrepreneurship (37\% of the surveyed students had completed secondary school of business) increased students' optimism and confidence that they have the ability and knowledge needed for entrepreneurship. Their optimism was not based on practical experience in business (students had some theoretical knowledge but no practical experience - only $17 \%$ of respondents are or used to be employed, while $13 \%$ attempted to start or started their own business). Most respondents were not informed about problems associated with starting a business and doing business in $\mathrm{BiH}$, i.e. challenges entrepreneurs are facing. Salamouris (2013, p. 4) claimed that "overconfidence replaces lack of information by overestimating ability".

Mind-set/culture: Mind-set and culture can partly explain students' enthusiasm and overconfidence. As already pointed out, the responses pertaining to their motives for engaging in entrepreneurship suggest that they are opportunity-driven, rather than necessity-driven, which is consistent with the findings of the GEM study, which reveals (contrary to expectations) that there is a high share of opportunity entrepreneurs in $\mathrm{BiH}$. Indeed, in less devel- oped and transition countries, the entrepreneurial activity index (TEA index) is high and necessity entrepreneurs are more common. However, this is not the case in $\mathrm{BiH}$. BiH has a high share of both opportunity and necessity entrepreneurs. This phenomenon was not sufficiently explored and understood, but it certainly has to do with expectations and attitudes of entrepreneurs in $\mathrm{BiH}$, i.e. with the mind-set/culture.

A great number of authors across the world studied the effect of culture and cultural factors on entrepreneurial intention. Many of them have confirmed that cultural differences affect entrepreneurial intention (Shapero \& Sokol, 1982; Thornton et al., 2011; Swail et al., 2014). Culture can shape individual propensity for entrepreneurship, i.e. affect the willingness to engage in it (Giacomin et al., 2016). Achieving a higher social status through entrepreneurship (Begley \& Tan, 2001) and social recognition of entrepreneur role can positively affect entrepreneurial intention (Entrepreneurial activity has value for society at large - average rating 5.27; Entrepreneurs have a high status in society - rating 4.94; Entrepreneurship will help me earn a high income - established statistical significance, rating 5.46).

Hofstede (2001) found that there are cultural differences across nations, which are manifested in in attitudes, values and behaviour, and that they affect entrepreneurship intentions as well as employees' behaviour. On the example of 50 countries, Hofstede identified five dimensions of culture pertaining to power distance, uncertainty avoidance, individualism vs. collectivism, masculinity vs. femininity, and long- vs. short-term orientation, and used them to determine differences between countries/ cultures. The GLOBE project (Javidan et al., 2004; House et al., 2004) as a "cross-cultural study of interrelationships between societal culture, societal effectiveness and organisational leadership" encompassed 60 countries and 700 organisations, and identified five dimensions that link entrepreneurial activity and society: assertiveness, performance orientation, collectivism, gender equality, and uncertainty avoidance. The dimensions described in this study are largely consistent with cultural dimensions identified by Hofstede.

Seeking to determine the effect of cultural differences on optimism and confidence that affect entrepreneurial intention, Giacomin et al. (2016) conducted extensive research among student pop- 
ulation of three countries, which, according to the described cultural dimensions, belong to different clusters: Spain, the USA and India. They studied the effect of students' perception of the significance of barriers to starting a business, perception of the significance of success in entrepreneurship, and expectations related to parents' support and entrepreneurial intention. In all three countries, students were found to be optimistic about starting a business and achieving business success (US students were the most optimistic), but there was no overconfidence. "Parents' support" was included as a moderating variable, but it was not statistically significant.

The study found that the respondents were selfconfident but not overconfident. These results can be explained by the fact that the respondents were final-year students aged 25 to 34, i.e. "older" students. The research did not establish any differences between student groups based on cultural differences, except in the degree of optimism related to entrepreneurship.

We believe that a more comprehensive comparative study should be conducted to examine the effect of culture on BiH students' entrepreneurial intentions and their optimism and overconfidence with regard to entrepreneurship.

Effect of environment - parents: parents' influence on respondents' views and understandings should be identified as a separate cultural factor that affects students' entrepreneurial intention in general and social entrepreneurial intention. Parents' views and experience greatly affect young people's views and entrepreneurial intention (Shapero \& Sokol, 1982; Giacomin et al., 2016). This research revealed that students have some support from their parents when they decide to start a business or engage in social entrepreneurship, although both respondents and their parents prefer the security of public sector employment (rating: 4.94).

\section{Research limitations}

The limitation of this research lies in the structure of the research sample - the respondents are firstyear students who have no (life or entrepreneurial) experience (do not have sufficient theoretical and practical knowledge). Most respondents completed a secondary school of business, which is to a great degree the reason for overestimating their knowledge and ability (although most respondents con- firmed that they have no experience but only basic knowledge of economics). An additional research limitation pertains to the limited coverage of respondents. It is possible that the results would have been different if the survey had included students from a greater number of faculties or students from a greater number of faculties of economics. Due to the fact that the respondents' age and their previous experience affect their opinions of entrepreneurial ability and conditions of environment, which in turn affect their entrepreneurial intention, it would be advisable for further research to include also final-year students, or broader population, i.e. respondents with more practical experience.

The survey provided a large amount of data; however, the questionnaire comprised 45 questions and statements, which was perhaps a limiting factor in research quality (too many questions causing questionnaire fatigue). A great number of questions together with the limited sample size and diversity may be the reason why several variables were not found to be significant; however, this should be tested by increasing the sample size and/or diversity. Place of residence, income and parents' education level were not found to have a statistically significant effect on the respondents' entrepreneurial intention. However, one should mention here that a great number of respondents did not provide information on the total household income, place of residence, and their parents' education. In many studies, these demographic factors were found to have an important effect on the respondents' entrepreneurial intention.

\section{Conclusion}

The conducted research revealed that young people in Bosnia and Herzegovina understand the significance of social entrepreneurship for society at large, as well as for themselves, i.e. personal satisfaction. The respondents did not have entrepreneurial experience or knowledge but they expressed willingness to engage in entrepreneurship in general and in social entrepreneurship, and are confident that they will achieve success in entrepreneurship. Most students indicated altruistic motivations for engagement in social entrepreneurship, i.e. a desire to contribute to society at large, a desire to improve employees' position, and achieve self-fulfilment.

Research results show that two variables have a statistically significant (positive) effect on perceived 
feasibility. Entrepreneurial self-efficacy (respondents' entrepreneurial self-confidence) and locus of control (respondents' belief that they will achieve the desired goals through their own effort and actions). One variable has a statistically significant (positive) effect on perceived desirability: wealth objective (wellbeing related to the possibility to earn a high income).

The research was aimed at identifying motivational factors that play a dominant role in entrepreneurial intentions of young people in $\mathrm{BiH}$, i.e. at exploring how the perceived feasibility and perceived desirability as mediators affect the intention to engage in entrepreneurship in general and in social entrepreneurship. The research encompassed personal and (semi)situational factors (as motivators) and was expanded with the socio-economic factors (political, regulatory, social, etc.), thereby contributing to the existing literature, i.e. studies based on the models developed by Barton et al. (2018) and Krueger (1993). In addition, the survey questionnaire was expanded with questions which inquire about the respondents' entrepreneurial intention in general. The goal was to determine students' willingness to engage in entrepreneurship in general, their motivations, perceived limitations to engaging in both traditional and social entrepreneurship, possible differences between them, as well as goals they aim to achieve when starting and developing a business - whether they are primarily profit-based or not. Although students emphasised the significance of social entrepreneurship and showed affinity for it (55\% of respondents expressed a desire to engage in social entrepreneurship, while $50 \%$ expressed a desire to engage in conventional entrepreneurship; respondents highlighted the significance of altruistic goals (improvement of society in general and improvement of employees' position), the only statistically significant variable that affected the perceived desirability was the wealth objective; it means that the primary desire to get involved in entrepreneurship is guided by a desire to generate high income. These results may suggest that a desirable entrepreneurial option for the respondents would be the one that implies involvement not in the social entrepreneurship but in the socially responsible entrepreneurship.

Research that would include a larger and more diversified sample, as well as comparative research among student population in different countries, would eliminate limitations of this research and give an additional contribution to the research into the issue of social entrepreneurship.

Regardless of the interpretations and possible additions to the obtained results, it is evident that education policymakers should introduce courses in both entrepreneurship and social entrepreneurship at the faculties of humanities and technical studies, while legislators should focus their efforts on the promotion and establishment of social entrepreneurship taking into account the dominant entrepreneurial motivations and intentions. 


\section{REFERENCES}

1. Ajzen, I. (1991). The Ajzen theory of planned behavior. Organizational Behavior and Human Decision Processes, 50(2), 179-211. https://doi.org/10.1016/0749-5978(91)90020-T

2. Abu-Saifan, S. (2012). Social Entrepreneurship: Definition and Boundaries. Technology Innovation Management Review, 2(2), 22-27. https://doi.org/10.22215/timreview/523

3. Austin, J. E. (2004). Social partnering in Latin America: Lessons drawn from collaborations of businesses and civil society organizations. Harvard University, David Rockefeller.

4. Barton, M., Schaefer, R. \& Canavati, S. (2018). To Be or Not to Be a Social Entrepreneur: Motivational Drivers amongst American Business Students. Entrepreneurial Business and Economics Review, 6(1), 9-35. https://doi.org/10.15678/EBER.2018.060101

5. Begley, T. M. \& Tan, W. L. (2001). The socio-cultural environment for entrepreneurship: A comparison between East Asian and Anglo Saxon countries. Journal of International Business Studies, 32(3), $537-$ 553. https://doi.org/10.1057/palgrave.jibs.8490983

6. Bell, P. \& Vockmann, D. (2011). Knowledge surveys in general chemistry: Confidence, overconfidence and performance. Journal of Chemical Education, 88(11), 1469-1476.

https://doi.org/10.1021/ed100328c

7. Braga, J. C., Proenca, T. \& Ferreira, M. R. (2015). Motivations for social entrepreneurship evidences from Portugal. Tékhne-Review of Applied Management Studies, 12(1), 11-21.

https://doi.org/10.1016/j.tekhne.2015.01.002

8. Bornstein, D. (1998). Changing the world on shoestring. The Atlantic Monthly, (1), 34-39.

9. Dees, J. G. (1998). The Meaning of Social Entrepreneurship. Kauffman Foundation and Stanford University.

10. Forbes, D. P. (2005). Are some entrepreneurs more overconfident than others?. Journal of Business Venturing, 20(5), 624-640. https://doi.org/10.1016/j.jbusvent.2004.05.001

11. Germak, A. J. \& Robinson, J. A. (2013). Exploring the Motivation of Nascent Social Entrepreneurs. Journal of Social Entrepreneurship, 5(1), 5-21. https://doi.org/10.1080/19420676.2013.820781

12. Giacomin, O., Janssen, F. \& Shinnar, R. S. (2016). Student entrepreneurial optimism and overconfidence across cultures. SAGE Journals, 34(7), 925-947. https://doi.org/10.1177/0266242616630356

13. Grimes, P. W. (2002). The Overconfident Principles of Economic Student: An Examination of a Metacognitive Skill. The Journal of Economic Education, 33(1), 15-30.

https://doi.org/10.1080/00220480209596121

14. Henton, D., Melville, J. \& Walesh, K. (1997). The Age of the Civic Entrepreneur: Restoring Civil Society and Building Economic Community. National Civic Review, 86(2), 149-156.

https://doi.org/10.1002/ncr.4100860208

15. Hofstede, G. (2001). Culture’s Consequences: Comparing Values, Behaviors, Institutions and Organizations Across Nations. SAGE Publications.

16. House, R. J., Hanges P. J. \& Javidan, M. (2004). The GLOBE Study of 62 Societies. SAGE Publications.

17. International Swedish Institute for Public Administration (2012). Izvještaj o procjeni socijalnog poduzetništva u Bosni i Hercegovini.

https://www.sif.ba/dok/izvjestaj-o-procjeni-socijalnog-poduzetnistva-u-BiH_web.pdf

18. Javidan, M, House, R. J. \& Dorfman, P. W. (2004). A nontechnical summary of GLOBE findings. In House, R. J. et al. (Eds.), Culture, Leadership and Organizations: The GLOBE Study of 62 Societies. SAGE Publications.

19. Krueger, N. F. (1993). The impact of prior entrepreneurial exposure on perceptions of new venture feasibility and desirability. Entrepreneurship Theory and Practice, 18(3), 5-21.

https://doi.org/10.1177/104225879301800101 
20. Leadbeater, C. (1997). The Rise of the Social Entrepreneur. Demos.

21. Leadbeater, C. \& Goss, S. (1998). Civic Entrepreneurship. Demos.

22. Mair, J. \& Marti, I. (2006). Social entrepreneurship research: A source of explanation, prediction, and delight. Journal of World Business, 41(1), 36-44. https://doi.org/10.1016/j.jwb.2005.09.002

23. Martinović, D. (2014). Privredni razvoj - politike malih i srednjih poduzeća. Vanjskopolitička inicijativa $\mathrm{BiH}$.

24. Moore, A. J. \& Prabhu, V. P. (2018). Towards an Understanding of Social Entrepreneurship: Traits and Learned Behavior. Journal of Strategic Innovation and Sustainability, 13(3), 114-128. https://doi.org/10.33423/jsis.v13i3.623

25. Nga, J. \& Shamuganathan, G. (2010). The influence of personality traits and demographic factors on social entrepreneurship start up intentions. Journal of Business Ethics, 95(2), 259-282. https://doi.org/10.1007/s10551-009-0358-8

26. Noruzi, M. R., Westover, J. H. \& Rahimi, G. R. (2010). An exploration of social entrepreneurship in the entrepreneurship era. Asian Social Science, 6(6), 3-10. https://doi.org/10.5539/ass.v6n6p3

27. Nowell, C. \& Alston, R. M. (2007). I thought I got an A! Overconfidence across the economics curriculum. Journal of Economic Education, 38(2), 131-142. https://doi.org/10.3200/JECE.38.2.131-142

28. Perry, J. L. (1996). Measuring Public Service Motivation: An Assessment of Construct Reliability and Validity. Journal of Public Administration Research, 6(1), 5-22. https://doi.org/10.1093/oxfordjournals.jpart.a024303

29. Perry, J. L. \& Wise, L. (1990). The Motivational Bases of Public Service. Public Administration Review, 50(3), 367-373. https://doi.org/10.2307/976618

30. Prabhu, G. N. (1999). Social Entrepreneurship Leadership. Career Development International, 4(3), 140-145. https://doi.org/10.1108/13620439910262796

31. Rantanan, T., Pawlak, A. \& Toikko, T. (2015). The Significance of Social Welfare Attitudes in Young People's Entrepreneurial Intentions. Entrepreneurial Business and Economics Review, 3(1), 43-60. https://doi.org/10.15678/EBER.2015.030104

32. Roger, L. M. \& Osberg, S. (2007). Social Entrepreneurship: The Case for Definition. Stanford Social Innovation Review, 5(2), https://ssir.org/articles/entry/social_entrepreneurship_the_case_for_definition

33. Robinson, J., Mair, J. \& Hockerts, K. (2009). International Perspectives on Social Entrepreneurship. Palgrave Macmillan.

34. Salamouris, I. S. (2013). How overconfidence influences entrepreneurship. Journal of Innovation and Entrepreneurship, 2(1), 1-6. https://doi.org/10.1186/2192-5372-2-8

35. Saunders, S. A., Nolan, J. \& Provost, S. (2009). Student attributions and performance: Problems with unfounded optimism?. Research in Higher Education Journal, 5, 1-8.

36. Shapero, A. \& Sokol, L. (1982). Social dimensions of entrepreneurship. In Kent, C. A. et al. (Eds.), Encyclopedia of Entrepreneurship (pp. 72-90). Prentice Hall.

37. Shaw, E. \& Carter, S. (2007). Social Entrepreneurship: Theoretical Antecedents and Empirical Analysis of Entrepreneurial Processes and Outcomes. Journal of Small Business and Enterprise Development, 14(3). https://doi.org/10.1108/14626000710773529

38. Spahić, E. \& Šarić, N. (2017). Socijalno poduzetništvo u funkciji ostvarivanja socio-ekonomskog razvoja lokalnih zajednica Federacije Bosne i Hercegovine. DHS, 3, 417-440.

39. Swail, J., Down, S. \& Kautonen, T. (2014). Examining the effect of 'entre-tainment' as a cultural influence on entrepreneurial intentions. International Small Business Journal, 32(8), 859-875. https://doi.org/10.1177/0266242613480193

40. Thompson, J., Alvy, G. \& Less, A. (2000). Social entrepreneurship: A new look at the people and the potential. Management Decision, 38(5), 328-338. https://doi.org/10.1108/00251740010340517 
41. Thornton, P. H., Ribeiro-Soriano, D. \& Urbano, D. (2011). Socio-cultural factors and entrepreneurial activity: An overview. International Small Business Journal, 29(2), 105-118.

https://doi.org/10.1177/0266242610391930

42. Trevelyan, R. (2008). Optimism, overconfidence and entrepreneurial activity. Management Decision, 46(7), 986-1001. https://doi.org/10.1108/00251740810890177

43. Yunus, M. (2011). Building Social Business - The New Kind of Capitalism that Serves Humanity's Most Pressing Needs. Public Affairs.

44. Wong, L. \& Tang. J. (2007). Dilemmas Confronting Social Entrepreneurs: Care Homes for Elderly People in Chinese Cities. Pacific Affairs, 79(4), 623-640. https://doi.org/10.5509/2006794623

45. Zahra, Sh. A., Gedajlovic, E., Neubaumm, D. O. \& Shulman, J. (2008). A Typology of Social Entrepreneurs: Motives, Search Processes and Ethical Challenges. Journal of Business Venturing, 24(5), 519532. https://doi.org/10.1016/j.jbusvent.2008.04.007 


\section{Appendix}

Research results presented by means of descriptive statistics (SEM)

\begin{tabular}{|c|c|c|c|c|c|}
\hline Variable & Obs & Mean & Std. Dev. & Min & $\operatorname{Max}$ \\
\hline eex01 & 82 & 0.23 & 0.42 & 0 & 1 \\
\hline edu_av2 & 84 & 4.09 & 1.46 & 1.00 & 7.00 \\
\hline ese_av & 84 & 5.25 & 1.10 & 1.43 & 7.00 \\
\hline lc_av1 & 85 & 5.54 & 1.31 & 1.50 & 7.00 \\
\hline wo & 85 & 5.46 & 1.23 & 1.00 & 7.00 \\
\hline sro & 85 & 5.65 & 1.27 & 2.00 & 7.00 \\
\hline auth & 85 & 5.32 & 1.26 & 2.00 & 7.00 \\
\hline auto & 85 & 5.56 & 1.41 & 1.00 & 7.00 \\
\hline $\mathrm{CO}$ & 85 & 5.78 & 1.15 & 1.00 & 7.00 \\
\hline pf_av & 83 & 5.54 & 1.14 & 1.50 & 7.00 \\
\hline pd_av & 81 & 4.61 & 1.24 & 1.00 & 7.00 \\
\hline male & 87 & 0.34 & 0.48 & 0 & 1 \\
\hline age & 86 & 19.14 & 0.72 & 18 & 22 \\
\hline sei & 87 & 0.55 & 0.50 & 0 & 1 \\
\hline
\end{tabular}

Source: Authors' calculations 